\title{
PHYTOCHEMICAL STUDY OF IXORA FINLAYSONIANA WALL. EX.G.DON GROWING IN EGYPT
}

Faten M. M. Darwish and Zedan Z. Ibraheim

Department of Pharmacognosy, Faculty of Pharmacy, Assiut University, Assiut, Egypt.

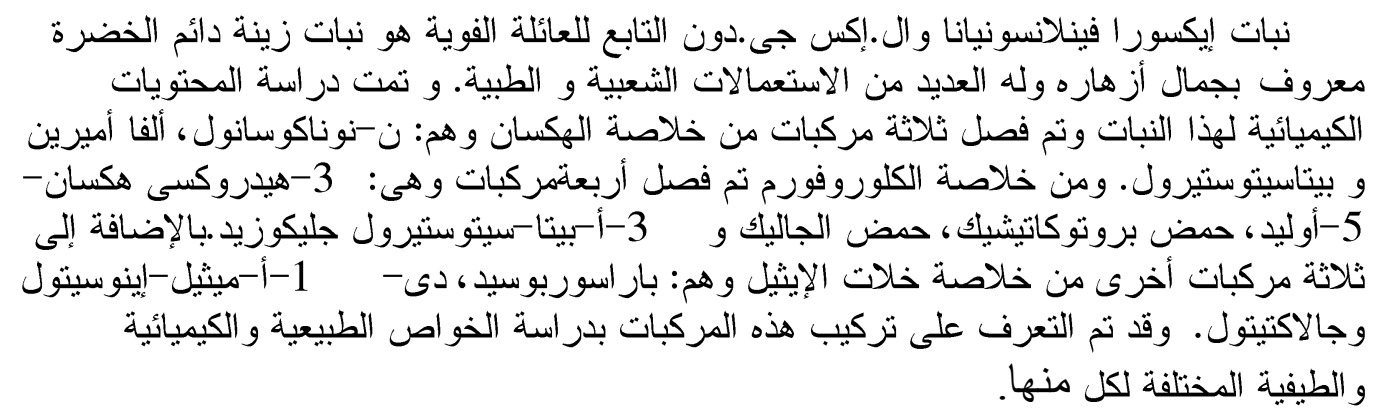

A hydrocarbon alcohol, nonacosanol (1), $\alpha$-amyrin (2) and $\beta$-sitosterol (3) were isolated from the $n$-hexane fraction of the methanolic extract of Ixora finlaysoniana. From the chloroform fraction, four compounds were isolated; 3-hydroxyhexan-5-olide (4), protocatechuic acid (5), gallic acid (6) and $\beta$-sitostreol glucoside (7). In addition to three compounds were isolated form the ethyl acetate fraction; parasorboside (8), D-1-O-methylmyo-inostiol (9) and galactitol (10). The structures of the isolated compounds were elucidated on the basis of physical, chemical and spectroscopic evidence.

\section{INTRODUCTION}

The genus Ixora (Rubiaceae) comprises about 200 species distributed through the warm regions in the tropics. ${ }^{1-3}$ Ixora finlaysoniana Wall.ex.G.Don. is a handsome woody shrub with showy flowers in clusters and evergreen foliage. ${ }^{3,4}$ Though, the plants of the genus Ixora are cultivated for ornamental purposes, some species have been used in traditional medicine. Ixora wood is febrifuge and the root is aperient, diuretic and deobstruent. ${ }^{5}$ The flowers of $I$. coccinea $\mathrm{L}$. have been used against leucorrhea and catarrhal bronchitis ${ }^{6}$ and for dysentery, healing of ulcers and have antiinflammatory and antitumor activities. ${ }^{7,8}$ The plant also showed chemoprotective effect on cyclophosphamide-induced toxicity by increasing the life span of treated mice. ${ }^{9} I$. chinensis is used to treat headache and stomachache and as a remedy for incipient tuberculosis. ${ }^{6}$ The dried entire plant of Ixora finlaysoniana is used in Thailand as a strength medicine, ${ }^{10}$ while the ethanolic extract of the plant was proved to have estrogenic, abortifacient and anti-implantation effects. ${ }^{11}$

The chemical composition of some Ixora species have been carried out. Phenolic acids and flavonoidal glycosides were isolated from I. Undulata, ${ }^{12}$ while chrysin-5-O- $\beta-\mathrm{D}$ xylopyranoside was isolated from the stem of $I$. arborea. ${ }^{13} \mathrm{~A}_{18}$ conjugated tetraenoic acid was isolated from I. chinensis seed oil. ${ }^{14}$ Additionally, some antitumor principles, mainly phenolic acids, were isolated from $I$. Javanica. $^{15}$

Reviewing the current literature for the chemical composition of Ixora finlaysoniana ${ }^{16}$ recovered only the isolation of apigenin-4'-O$\beta$-D-glucopyranoside and 11-hydroxy-dodec-5en-2-one. The botanical study of the stem and leaf of Ixora finlaysoniana cultivated in Egypt was previously carried out. ${ }^{17}$ 


\section{EXPERIMENTAL}

\section{I- Plant material}

The plant material used in this work was collected in Aswan Botanical Garden, Aswan, Egypt in March 1998. The plant was kindly authenticated by the Royal Botanical Garden KEW. A voucher specimen was deposited in the Herbarium of the Pharmacognosy Department, Faculty of Pharmacy, Assiut University, Assiut.

\section{II- General procedure}

1- Melting points were determined using electrothermal digital instrument without correction.

2- EIMS were recorded on a JEOL mass. spectrometer at $70 \mathrm{ev}$.

3- ${ }^{1} \mathrm{H}$ and ${ }^{13} \mathrm{C}$-NMR were recorded on a JEOL spectrometer at 400 and $270 \mathrm{MHz}$ for ${ }^{1} \mathrm{H}$ NMR and 100 and $67.5 \mathrm{MHz}$ for ${ }^{13} \mathrm{C}-\mathrm{NMR}$ using DMSO and $\mathrm{CD}_{3} \mathrm{OD}$ as solvent, chemical shift values are reported in $\delta \mathrm{ppm}$ relative to that of TMS as internal standard and coupling constants are given in $\mathrm{Hz}$.

4- Column chromatography was carried out on silica gel 60 (E-Merck, 70-230 mesh) and prepacked column for MPLC (CIG column system, $22 \mathrm{~mm}$, i.d. x $30 \mathrm{~cm}$, Kusano Scientific Co. Tokyo, Japan). Monitoring with TLC was carried out on precoated sheets (Kieselgel $60 \mathrm{~F}_{254}$, Merck). The spots were visualized by spraying with $10 \%$ aqueous sulfuric acid and heating at $110^{\circ}$.

5- Solvent systems

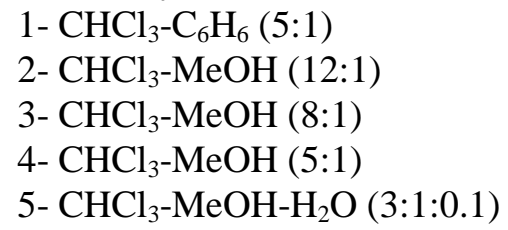

\section{III- Extraction and isolation}

The air-dried leaves and stems of Ixora finlaysoniana $(600 \mathrm{~g})$ were extracted by percolation with methanol for three times (4 L, each) at room temperature. The combined methanol extracts were evaporated under vacuum to yield crude extract $(60 \mathrm{~g})$. The dried methanol extract was suspended in distilled water $(1 \mathrm{~L})$ and partitioned with $\mathrm{n}-\mathrm{C}_{6} \mathrm{H}_{12}(1 \mathrm{~L} \mathrm{x}$ 3), $\mathrm{CHCl}_{3}(1 \mathrm{Lx} 3)$ and EtOAc (1L x 3), successively. Each extract was evaporated under vacuum till dryness.
The $\mathrm{n}-\mathrm{C}_{6} \mathrm{H}_{12}$ fraction (10 g, dark green residue) was subjected to silica gel column chromatography (400 g) using gradient $n-\mathrm{C}_{6} \mathrm{H}_{12}$ $-\mathrm{CHCl}_{3}$ system. The fractions 22-27 (1 g, n$\mathrm{C}_{6} \mathrm{H}_{12}-\mathrm{CHCl}_{3}$ 65:35) were further purified by repeated silica gel column chromatography to give compounds $1\left(50 \mathrm{mg}, \mathrm{R}_{\mathrm{f}} 0.83\right.$, solvent system 1$), 2$ (70 mg, $R_{\mathrm{f}} 0.80$, solvent system 2 ) and $\mathbf{3}$ (300 $\mathrm{mg} \mathrm{R}_{\mathrm{f}} 0.66$, solvent system2).

The $\mathrm{CHCl}_{3}$ fraction (10 g, faint brown residue) was subjected to silica gel column chromatography (400 g) using gradient $\mathrm{CHCl}_{3-}$ $\mathrm{MeOH}$ system. The fractions 20-24 (500 mg, $\mathrm{CHCl}_{3}-\mathrm{MeOH}$ 85:15) were subjected to repeated moderate pressure column chromatography (MPLC), [silica gel prepacked column] using $\mathrm{CHCl}_{3}-\mathrm{MeOH}$ (9:1) to give compounds 4 (100 mg, $\mathrm{R}_{\mathrm{f}} 0.52$, solvent system $2)$ and $5\left(120 \mathrm{mg}, R_{\mathrm{f}} 0.61\right.$, solvent system 3$)$. Fractions 32-40 (2 g, $\mathrm{CHCl}_{3}-\mathrm{MeOH}$ 8:2) were further purified by repeated silica gel column chromatography using gradient $\mathrm{CHCl}_{3}-\mathrm{MeOH}$ to give compound $6\left(500 \mathrm{mg}, \mathrm{R}_{\mathrm{f}} 0.54\right.$, solvent system 3$)$ and compound $7\left(350 \mathrm{mg}, \mathrm{R}_{\mathrm{f}} 0.50\right.$, solvent system 3 ).

The EtOAc fraction (15 g, yellowish brown residue) was chromatographed over silica gel column $(500 \mathrm{~g})$, elution was carried out with $\mathrm{CHCl}_{3}$ increasing the polarity with $\mathrm{MeOH}$ gradiently up to (1:1). Fractions 14-19 eluted with $\mathrm{CHCl}_{3}-\mathrm{MeOH} \quad(85: 15)$ were combined and evaporated under vacuum to give a residue $(800 \mathrm{mg})$ which was rechromatographed over silica gel column with gradient $\mathrm{CHCl}_{3}-\mathrm{MeOH}$ system to give compounds 8 ( $330 \mathrm{mg}, \mathrm{R}_{\mathrm{f}}$ : 0.72 , solvent system 4) and 9 (100 mg, $R_{f}: 0.67$, solvent system 4$)$. Fractions 22-26 eluted with $\mathrm{CHCl}_{3}-\mathrm{MeOH}$ (75:25) were combined and evaporated under vacuum to give a residue $(150 \mathrm{mg})$ which was rechromatographed over silica gel column with a mixture of $\mathrm{CHCl}_{3}-\mathrm{MeOH}$ (3:1) to give compound $\mathbf{1 0}$.

n-Nonacosanol (1): White wax, EI-MS, $\mathrm{m} / \mathrm{z}$ (\% rel. int.) $424[\mathrm{M}]^{+}$(3.1) calculated for $\mathrm{C}_{29} \mathrm{H}_{60} \mathrm{O}, 385$ (3), 365 (4), 337 (6), 314 (7), 284 (8.), 255 (13), 238 (11), 196 (12), 189 (12), 165 (12), 125 (18), 109 (30), 95 (41), 83 (44), 71 (61), 57 (89) and 43 (100). ${ }^{1} \mathrm{H}-\mathrm{NMR}\left(\mathrm{CDCl}_{3}\right)$ $\delta_{\mathrm{H}}: 0.87(\mathrm{t}, J=7.2 \mathrm{~Hz}), 1.25\left(\mathrm{~m}, \mathrm{CH}_{2}\right), 1.65(\mathrm{~m}$, $\left.\mathrm{CH}_{2}\right), 2.3(\mathrm{t}, J=7.8 \mathrm{~Hz}), 4.05(\mathrm{t}, J=6.4 \mathrm{~Hz})$, 4.56 (br. s.). ${ }^{13} \mathrm{C}-\mathrm{NMR} \quad\left(\mathrm{CDCl}_{3}\right) \quad \delta_{\mathrm{C}}: \quad 62.4$ 


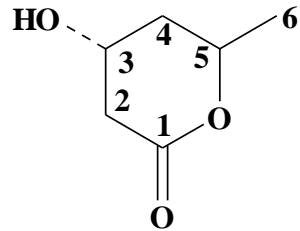

(4)<smiles>O=C(O)c1ccc(O)c(O)c1</smiles>

(5)<smiles>O=C(O)c1cc(O)c(O)c(O)c1</smiles>

(6)

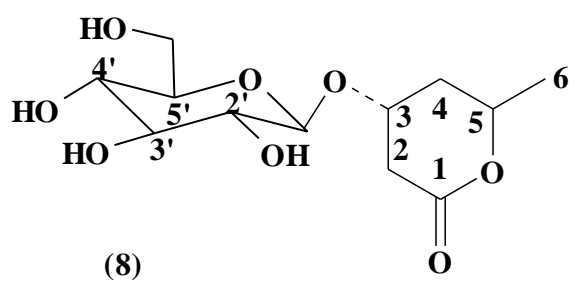<smiles>CO[C@H]1C(O)[C@H](O)[C@@H](O)C(O)(O)[C@H]1O</smiles>

(9)<smiles>OCC(O)C(O)C(O)C(O)C(O)CO</smiles>

(10)

Compounds isolated from Ixora finlaysoniana

$\left(\mathrm{t}, \underline{\mathrm{CH}_{2}} \mathrm{OH}\right), 34.4(\mathrm{t}), 31.9-29.7(\mathrm{t}), 22.7(\mathrm{t}$, $\left.\mathrm{CH}_{2}-\mathrm{CH}_{3}\right)$ and 14.1 (q, $\left.\mathrm{CH}_{3}\right)$.

3-Hydroxyhexan-5-olide (4): Faint yellow oil, EIMS, m/z (\% rel. int.): $131[\mathrm{M}+1]^{+}(12)$, $130\left[(\mathrm{M})^{+}, \mathrm{C}_{6} \mathrm{H}_{10} \mathrm{O}_{3}\right](8), 115\left[\mathrm{M}-\mathrm{CH}_{3}\right]^{+}$(5), 113 $[\mathrm{M}-\mathrm{OH}]^{+}$(20), 102 [M-CO] $^{+}$(4), 97 (35), 86 $\left[\mathrm{M}-\mathrm{CH}_{3} \mathrm{CHO}\right]^{+}(30), 96\left[\mathrm{M}-\left(\mathrm{CH}_{3} \mathrm{CHO}+\mathrm{HO}\right)\right]^{+}$ (50), 57 (80), 50 (54) and 43 (100). ${ }^{1} \mathrm{H}-\mathrm{NMR}$ (DMSO) $\delta_{\mathrm{H}}: 1.26\left(3 \mathrm{H}, \mathrm{d}, J=6.4 \mathrm{~Hz}, \mathrm{CH}_{3}-6\right)$, $1.58(1 \mathrm{H}$, ddd, $J=14.5,11.0,3.0 \mathrm{~Hz}, \mathrm{H}-4 \beta)$, $2.30(1 \mathrm{H}, \mathrm{m}, \mathrm{H}-4 \alpha), 2.65(1 \mathrm{H}, \mathrm{dd}, J=17.2,4.0$ $\mathrm{Hz}, \mathrm{H}-2 \beta), 2.94(1 \mathrm{H}, \mathrm{m}, \mathrm{H}-2 \alpha) 4.36(1 \mathrm{H}, \mathrm{m}$, $\mathrm{H}-3)$ and 4.88 (1H, m, H-5). ${ }^{13} \mathrm{C}-\mathrm{NMR}$ (DMSO) $\delta_{\mathrm{C}}: 169.0$ (s, C-1), 72.8 (d, C-5), 67.4 (d, C-3), 38.1 (t, C-2), 35.6 (t, C-4) and 20.8 (q, C-6).

Protocatechuic acid (5): Faint brown amorphous powder, ${ }^{1} \mathrm{H}-\mathrm{NMR}$ (DMSO), $\delta_{\mathrm{H}}$ : $12.20(\mathrm{COOH}), 9.20(\mathrm{OH}-3), 9.18(\mathrm{OH}-4), 6.92$ (m, H-2, H-5, H-6). ${ }^{13} \mathrm{C}-\mathrm{NMR}$ (DMSO), $\delta_{\mathrm{C}}$ : 167.4 (C-7), 145.6 (C-4), 145.1 (C-3), 120.4 (C-1), 110.6 (C-6), 109.3 (C-5) and 108.5 (C-2).
Gallic acid (6): Faint brown crystals, m.p 239-241 ${ }^{\circ}, \quad{ }^{1} \mathrm{H}-\mathrm{NMR} \quad$ (DMSO), $\quad \delta_{\mathrm{H}}: \quad 12.2$ $(\mathrm{COOH}), 9.22(\mathrm{OH}-3, \mathrm{OH}-5), 8.94(\mathrm{OH}-4)$, $6.93(2 \mathrm{H}, \mathrm{s}, \mathrm{H}-2, \mathrm{H}-6) .{ }^{13} \mathrm{C}-\mathrm{NMR}$ (DMSO), $\delta_{\mathrm{C}}$ : 167.4 (C-7), 145.3 (C-3, C-5), 137.9 (C-4), 120.3 (C-1), 108.0 (C-2, C-6).

Parasorboside (8): White amorphous powder, EIMS, m/z (\% rel. int.): $292[\mathrm{M}]^{+}$(4), $131[\mathrm{M}+1 \text { of aglycone }]^{+}(70), 130$ [(M-162), M-hexose ${ }^{+}$(4), 115 (15), 113 (5), 102 (90), 97 (19), 86 (26), 73 (100), 69 (56), 57 (87), 55 (68) and 43 (97). ${ }^{1} \mathrm{H}-\mathrm{NMR}$ (DMSO), $\delta_{\mathrm{H}}: 1.26$ $\left(3 \mathrm{H}, \mathrm{d}, J=6.4 \mathrm{~Hz}, \mathrm{CH}_{3}-6\right), 1.61$ (1H, ddd, $J=$ 14.2, 11.2, $2.8 \mathrm{~Hz}, \mathrm{H}-4 \beta), 2.26$ (1H, m, H-4 $\alpha$ ), $2.89(1 \mathrm{H}, \mathrm{dd}, J=17.5,4.0 \mathrm{~Hz}, \mathrm{H}-2 \beta), 3.04(1 \mathrm{H}$, m, H-2 $\alpha), 4.34$ (1H, m, H-3), 4.86 (1H, m, H5), $5.05(1 \mathrm{H}, \mathrm{d}, J=8 \mathrm{~Hz}, \mathrm{H}-1$ ' glucose $)$ and 3.75-4.86 (overlapping signals, H-2'-H-6' glucose). ${ }^{13} \mathrm{C}-\mathrm{NMR}$ (DMSO), $\delta_{\mathrm{C}}: 168.5$ (s, C1), 74.9 (d, C-5), 72.1(d, C-3), 36.5 (t, C-2), 34.2 (t, C-4), 22.4 (q, C-6), 104.0 (d, C-1'), 77.8 (d, C-5'), 77.0 (d, C-3'), 74.3 (d, C-2'), 71.6 (d, C-4'), 62.1 (t, C-6'). 
D-1-O-methyl-myo-inositol (9): White amorphous powder. EIMS, m/z (\% rel. int.) 194 $[\mathrm{M}]^{+}(26), 179$ (72), 163 (11), 162 (12), 145 (10), 102 (31), 98 (42), 85 (75), 54 (100). ${ }^{1} \mathrm{H}-$ NMR (DMSO) $\delta_{\mathrm{H}}: 3.57\left(3 \mathrm{H}, \mathrm{s}, \mathrm{OCH}_{3}\right), 3.33-$ $3.99(6 \mathrm{H}$, overlapping signals, $\mathrm{H}-1-\mathrm{H}-6) .{ }^{13} \mathrm{C}-$ NMR (DMSO) $\delta_{\mathrm{C}}: 81.6$ (d, C-1), 75.3 (d, C-5), 72.5 (d, C-3), 71.8 (d, C-6), 71.6 (d, C-4), 68.3 (d, C-2), 56.6 (q, $\mathrm{OCH}_{3}$ ).

Galactitol (10): Colorless prisms, m.p182$185^{\circ}$. EI-MS, m/z (\% rel. int.) $182[\mathrm{M}]^{+}(24)$, 164 (15), 146 (31), 145 (70), 133 (52), 132 (98), 121 (25),116 (54), 104 (42), 103 (71), 91 (51), 87 (35), 84 (35), 75 (35), 73 (83), 69 (42) and 31 (100). ${ }^{1} \mathrm{H}-\mathrm{NMR}$ (DMSO), $\delta_{\mathrm{H}}: 4.32(2 \mathrm{H}$, $\left.\mathrm{dd}, J=11.7,3.0 \mathrm{~Hz}, \mathrm{H}-1_{\mathrm{A}}, \mathrm{H}-6_{\mathrm{A}}\right), 4.12(2 \mathrm{H}, \mathrm{d}$, $J=7.1 \mathrm{~Hz}, \mathrm{H}-3, \mathrm{H}-4), 3.60(2 \mathrm{H}, \mathrm{m}, \mathrm{H}-2, \mathrm{H}-5)$, $3.50\left(2 \mathrm{H}, \mathrm{dd}, J=11.7,6.0 \mathrm{~Hz}, \mathrm{H}-1_{\mathrm{B}}, \mathrm{H}-6_{\mathrm{B}}\right)$. ${ }^{13} \mathrm{C}-\mathrm{NMR}$ (DMSO), $\delta_{\mathrm{C}}: 71.5$ (d, C-3, C-4), 69.9 (d, C-2, C-5), 64.1 (t, C-1, C-6).

\section{RESULTS AND DISCUSSION}

Fractionation of the n-hexane fraction of Ixora finlaysoniana by repeated column chromatography using silica gel (Experimental section) yielded compounds 1-3.

Compound 1 showed a molecular ion peak at $\mathrm{m} / \mathrm{z} 424$ calculated for $\mathrm{C}_{29} \mathrm{H}_{60} \mathrm{O}$ and was identified from its mass fragmentation pattern, ${ }^{1} \mathrm{H}$ - and ${ }^{13} \mathrm{C}-\mathrm{NMR}$ as a straight chain alkanol; n-nonacosanol. ${ }^{18}$

Compound 2 was identified as $\alpha$-amyrin and compound $\mathbf{3}$ was identified as $\beta$-sitosterol through their physical and chromatographic characteristics and by comparison with authentic samples.

The chloroform fraction of the plant was fractionated using a combination of silica gel column chromatography and MPLC (see experimental section) to yield four pure compounds (4-7).

The EI-mass spectrum of compound 4 showed $[\mathrm{M}+1]^{+}$peak at $\mathrm{m} / \mathrm{z} 131$ consistent with the molecular formula $\mathrm{C}_{6} \mathrm{H}_{10} \mathrm{O}_{3}$, which was, confirmed with ${ }^{13} \mathrm{C}-\mathrm{NMR}$ and DEPT experiments. The ${ }^{1} \mathrm{H}-\mathrm{NMR}$ spectra exhibited signals for a doublet methyl at $\delta_{\mathrm{H}} 1.26(3 \mathrm{H}, \mathrm{d}$, $J=6.4 \mathrm{~Hz}$ ), two methylene protons at $\delta_{\mathrm{H}} 1.58$ $(1 \mathrm{H}$, ddd, $J=14.5,11,3.0 \mathrm{~Hz})$ and $2.30(1 \mathrm{H}$, $\mathrm{m})$, other two methylene protons at $\delta_{\mathrm{H}} 2.65$ $(1 \mathrm{H}, \mathrm{dd}, J=17.2,4.0 \mathrm{~Hz})$ and $2.94(1 \mathrm{H}, \mathrm{m})$ and two oxygen bonded methine protons at $\delta_{\mathrm{H}} 4.36$
$(1 \mathrm{H}, \mathrm{m})$ and $4.88(1 \mathrm{H}, \mathrm{m})$. Furthermore, the ${ }^{13} \mathrm{C}-\mathrm{NMR}$ spectra showed signal for a methyl group at $\delta_{\mathrm{C}} 20.8(\mathrm{q})$,two signals for methylene carbons at $\delta_{\mathrm{C}} 38.1(\mathrm{t})$ and $35.6(\mathrm{t})$, two signals for oxygenated methine carbons at $\delta_{\mathrm{C}} 72.8$ (d) and 67.4 (d) and a lactone carbonyl carbon at $\delta_{\mathrm{C}} 169.0(\mathrm{~s})$. Based on these abovementioned data, compound 4 seemed to be a hexanolide ${ }^{19}$ with an oxygen substituent and a methyl group which was supported by comparison of its physical and spectral data with those published for other hexanolides. ${ }^{19,20}$ The ${ }^{1} \mathrm{H}-\mathrm{NMR}$ spectra indicated that $\mathrm{H}-3$ appeared at $\delta_{\mathrm{H}} 4.36$ and $\mathrm{H}-5$ at $\delta_{\mathrm{H}} 4.88$ clearly indicated the axial orientation of the former and equatorial orientation of the latter ${ }^{20}$ and this confirmed the structure of $\mathbf{4}$ as 3-hydroxyhexan-5-olide. This compound was previously isolated from Osmunda japonica ${ }^{19,20}$ but this is the first report for its isolation from the genus Ixora.

Compounds 5 and $\mathbf{6}$ were identified as protocatechuic acid and gallic acid respectively by comparing their physical and spectral data with those reported, ${ }^{21,22}$ while compound 7 was identified as sitosterol-3- $O-\beta$-D-glucoside by comparing with authentic sample.

The ethyl acetate fraction was fractionated using repeated silica gel column chromatography (see experimental section) to yield three pure compounds (8-10).

The ${ }^{1} \mathrm{H}-$ and ${ }^{13} \mathrm{C}-\mathrm{NMR}$ spectra of $\mathbf{8}$ showed signals closely similar to those of $\mathbf{4}$ in addition to signals attributed to one hexose moiety. The assignment of the ${ }^{1} \mathrm{H}-\mathrm{NMR}$ and ${ }^{13} \mathrm{C}$-NMR spectral data of $\mathbf{8}$ is described in the experimental section.

The significant downfield shift of C-3 in ${ }^{13} \mathrm{C}-\mathrm{NMR}$ of $8(+4.7 \mathrm{ppm})$ compared with that of $\mathbf{4}$ together with the upfield shift of C-2 (-1.6 ppm) and C-4 (-1.4 ppm) confirmed the attachment of the hexose moiety to C-3 of $4 .^{23}$ The carbon signals at $\delta_{\mathrm{C}} 104.0(\mathrm{~d}), 77.8$ (d), $77.0(\mathrm{~d}), 74.3(3), 71.6(\mathrm{~d})$ and $62.1(\mathrm{t})$ and the coupling constant of the anomeric proton in the ${ }^{1} \mathrm{H}-\mathrm{NMR}$ spectra $(J=8.0 \mathrm{~Hz})$ proved that the hexose moiety is $\beta$-D-glucopyranose. ${ }^{23,24}$

On the basis of these evidences the structure of $\mathbf{8}$ was presumed to be (3R, 5R)-3( $\beta$-glucopyranosyloxy)-5-hexanolide

(parasorboside) which has been isolated from Sorbus aucuparia L., ${ }^{25}$ Osmunda japonica ${ }^{20}$ and Hymenophyllum barbatum. ${ }^{26}$ This compound was reported to have a significant 
anti-feeding activity for larva of yellow butterfly Eurema hecabe mandarina. ${ }^{25}$

Compound 9 was obtained as an amorphous powder. Its molecular formula was suggested to be $\mathrm{C}_{7} \mathrm{H}_{14} \mathrm{O}_{6}$ from its EI-MS ${ }^{13} \mathrm{C}$ NMR and DEPT spectra. Its EI-MS showed a molecular ion peak at $\mathrm{m} / \mathrm{z} 194$, a base peak at $\mathrm{m} / \mathrm{z} 41$ and other major fragment ions at $\mathrm{m} / \mathrm{z}$ $179,163,162,145,102,98,85$ and 54 . The ${ }^{1} \mathrm{H}-$ NMR spectrum of 9 showed a singlet signal at $\delta_{\mathrm{H}} 3.57(3 \mathrm{H}, \mathrm{s})$ assigned for a methoxy protons in addition to a complex pattern of overlapping signals at $\delta_{\mathrm{H}} 3.33-3.99$ equivalent to six methine protons.

The ${ }^{13} \mathrm{C}-\mathrm{NMR}$ spectrum of 9 indicated the presence of a methoxy group $\left(\delta_{\mathrm{C}} 56.6\right)$ and six oxymethines $\left[\delta_{\mathrm{C}} 68.30(\mathrm{C}-2), 71.75\right.$ (C-4), 71.81 (C-6), 72.50 (C-3), 75.30 (C-5) and 81.60 (C-1)]. Comparing the above mentioned data with those reported indicated that these data are characteristic to myo-inositol derivatives, ${ }^{27,28}$ since in other inositol derivatives as scyllolinositol, all the carbon signals are identical (appeared at $\left.\delta_{\mathrm{C}} 73.7\right)^{23,28}$ and in L- chiroinositol, only three signals were appeared (at $\delta_{\mathrm{C}}$ 70.5, 71.6 and 72.8), while in epi-inositol, four signals were appeared $\left(\right.$ at $\delta_{\mathrm{C}} 71.7,74.5,70.1$ and 66.8). ${ }^{23,28}$

The downfield shift of C-1 of compound 9 $\left(\delta_{\mathrm{C}} 81.6\right)$ and the upfield shift of C-2 and C-6 together with the appearance of the methoxy group signal at $\delta_{\mathrm{C}} 56.6$ indicated that 9 is D-1$O$-methyl-myo-inositol ${ }^{23,28}$ previously isolated from Crotalaria trifoliastrum ${ }^{28}$ but it is the first time to be isolated from the genus Ixora.

Compound $\mathbf{1 0}$ was obtained as colorless prisms and exhibited a molecular formula $\mathrm{C}_{6} \mathrm{H}_{14} \mathrm{O}_{6}$ as determined by EI-MS and DEPT ${ }^{13} \mathrm{C}$-NMR spectra. In the ${ }^{13} \mathrm{C}$-NMR and DEPT spectra, only three carbon signals were appeared at $\delta_{\mathrm{C}} 71.5(\mathrm{~d} \times 2), 69.9(\mathrm{~d} \times 2)$ and $64.1(\mathrm{t} \times 2)$ suggested a hexose moiety. ${ }^{23}$ This was confirmed by the EI-MS which showed a molecular ion peak at $\mathrm{m} / \mathrm{z} 182$, other peaks at $\mathrm{m} / \mathrm{z} 164$ and 146 for successive loss of water molecules and a base peak at $\mathrm{m} / \mathrm{z} 31$ for $\mathrm{CH}_{2} \mathrm{OH}^{+}$group. In the ${ }^{1} \mathrm{H}-\mathrm{NMR}$ spectrum, four sets of protons were appeared at $\delta_{\mathrm{H}} 4.32(2 \mathrm{H}$, $\mathrm{dd}, J=11.7,3.0 \mathrm{~Hz}, \mathrm{H}-1_{\mathrm{A}}$ and $\left.\mathrm{H}-6{ }_{\mathrm{A}}\right), 4.12$ $(2 \mathrm{H}, \mathrm{d}, J=7.1 \mathrm{~Hz}, \mathrm{H}-3$ and $\mathrm{H}-4), 3.60(2 \mathrm{H}, \mathrm{m}$, $\mathrm{H}-2$ and $\mathrm{H}-5)$ and $3.50(2 \mathrm{H}, \mathrm{dd}, J=11.7$ and 6.0 $\mathrm{Hz}, \mathrm{H}-\mathrm{1}_{\mathrm{B}}$ and $\mathrm{H}-6_{\mathrm{B}}$ ).
Compound $\mathbf{1 0}$ was identified as galactitol by comparing its physical and spectral composition with the literature data. ${ }^{29,30}$ This is the first isolation of galactitol from the genus Ixora.

\section{REFERENCES}

1- A. B. Bendle, "The Classification of Flowering Plants" Cambridge, The University Press, Vol. II, Dicotyledones (1959).

2- B. D. Jackson, "Index Kewensis", The Clarendon Press, Oxford, Part II, 1245 (1893).

3- C. R. Metcalfe and L. Chalk, "Anatomy of Dicotyledones", The Clarendon Press, Oxford (1970).

4- L. HR Baily, "The Standard Cyclopedia of Horticulture", The Macmillan Co., New York, Vol. II (1960).

5- K. R. Kirtikar and B. D. Basu, "Indian Medicinal Plants" Prakash Publisher, New Delhi, Vol. II (1975).

6- L. M. Perry, "Medicinal Plants of East and Southeast Asia", The MIT Press, Cambridge, Massachusetts and London, England (1980).

7- R. G. Latha and K. R. Panikkar, Cancer Lett., 14, 130 (1-2), 197 (1998).

8- B. S. Nayak, A. L. Udupa and S. L. Udupa, Fitoterapia, 70, 233 (1999).

9- R. G. Latha and K. R. Panikkar, Phytotherp. Res., 13 (6), 217 (1999).

10- E. F. Andreson, Econ. Bot., 40 (1), 38-53 (1986).

11- M. M. Singh, S. R. Chowdhury, D. K. Kulshreshtha and U.V. P. Kamboj, Contraception, 48 (2), 178-191 (1993).

12- T. I. Khalifa, HR A. Ammar., M. Azizi and M. Hosny, Al-Azhar J. Nat. Product, 3, 23 (1989).

13- J. S. Chauhan, S. Kumar and R. Chaturvedi, Phytochemistry, 23 (10), 2404-2405 (1984).

14- H. Minquan, Phytochemistry, 29 (4), 1317-1319 (1990).

15- S. C. Nair and K. R. Panikkar, Cancer Lett., 49 (2), 121-126 (1990).

16- J. S. Chauhan and T. J. Vidyapati, Indian J. Chem. Sect. (B), 35 (9), 992-994 (1996). 
17- F. M. M. Darwish, Zagazig J. Pharm. Sci., 3 (3), 82-92 (1994).

18- A. B. Caldicott and G. Eghinton, Phytochemistry, 14, 1799 (1975).

19- A. Numata, K. Horimoto, T. Takemura, T. Katsundo and K. Yamamoto, Chem. Pharm., Bull., 32 (7), 2815-2820 (1984).

20- A. Numata, C. Takahashi, R. Fujiki, E. Kitano, A. Kitajima and T. Takemura, Chem. Pharm. Bull., 38 (10), 2862-2865 (1990).

21- E. Malarcz, I. Korszen-Pilecka and A. Leonowicz, Phytochemistry, 28 (2) 415 (1989).

22- H. E. Gottlieb, S. Kumar, M. Sahai and A. N. Ray, Phytochemistry, 30 (7), 3435 (1991).

23- E. Breitmaier and W. Voelter, "Carbon-13 NMR Spectroscopy" $3^{\text {rd }}$ Completely revised Ed., VCH (1987).
24- E. Breitmaier, "Structure Elucidation by NMR in Organic Chemistry-A Practical Guide", John Willy \& Sons, England (1993).

25- R. Tschesche, HR J. Hoppe, G. Snatzke, G. Wulff and HR W. Fehlhaber, Chem. Ber., 104, 1420 (1971).

26- M. Toyota, Y. Oiso and Y. Asakawa, Chem. Pharm. Bull., 49 (12), 1567-1572 (2001).

27- D. E. Dorman, S. L. Angyal and T. D. Roberts, J. Am. Chem. Soc., 92, 1351 (1970).

28- M. S. Rao, J. K. Kumar, P. S. Rao, G. Toth, A. Siman, B. Balazs and K. Duddeck, Fitoterapia, 70, 200-202 (1999).

29- W. Voelter, E. Breitmaier, E. B. Rathbone and E. M. Stephen, Tetrahedron, 29, 3845 (1979).

30- S. Fong, D. E. Berry, D. G. Lynn, S. M. Hecht, J. Campell and W. S. Lynne, Phytochemistry, 23 (3), 631-633 (1984). 